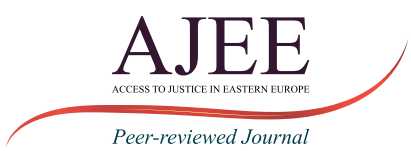

Access to Justice in Eastern Europe

ISSN 2663-0575 (Print)

ISSN 2663-0583 (Online)

Journal homepage http://ajee-journal.com

\title{
Note
}

\section{'PUBLIC ORDER'AS GROUNDS FOR REFUSAL IN THE RECOGNITION AND ENFORCEMENT OF A DECISION IN INTERNATIONAL COMMERCIAL ARBITRATION: UKRAINIAN REALITIES AND INTERNATIONAL EXPERIENCE}

\author{
Malinovska Iryna ${ }^{* 1}$ \\ i.m.malinovska@nlu.edu.ua \\ https://orcid.org/0000-0001-5945-2042

\section{Yarkina Natalya*2} \\ n.ye.yarkina@nlu.edu.ua \\ https://orcid.org/0000-0001-9026-9385
}

\section{Filiuk Oleksandra*3}

\section{Filiuk.alexandra@ltnu.ua}

(iD) https://orcid.org/0000-0003-1717-3146

1 Cand. of Science of Law (Equiv. Ph.D.), Assist. Prof. at Civil Law Department, Yaroslav Mudryi National Law University, Kharkiv, Ukraine. i.m.malinovska@nlu.edu.ua https://orcid.org/0000-0001-5945-2042 Corresponding author, responsible for conceptualization and methodology.

Competing interests: Any competing interests were announced.

Disclaimer: The author declares that her opinion and views expressed in this manuscript are free of any impact of any organizations.

Managing Editor - Dr. Serhii Kravtsov. English editing - Dr. Sarah White.

The content of this article was translated with the participation of third parties under the authors' responsibility.

Copyright: (C) 2022 I Malinovska, N Yarkina, O Filiuk. This is an open access article distributed under the terms of the Creative Commons Attribution License, (CC BY 4.0), which permits unrestricted use, distribution, and reproduction in any medium, provided the original author and source are credited.

How to cite: I Malinovska, N Yarkina, O Filiuk "Public Order" as Grounds for Refusal in the Recognition and Enforcement of a Decision in International Commercial Arbitration: Ukrainian Realities and International Experience' 2022 1(13) Access to Justice in Eastern Europe 154-164. DOI: https://doi.org/10.33327/AJEE-18-5.1-n000096

Published: 1 Febr 2022 (https://doi.org/10.33327/AJEE-18-5.1-n000096)

2 Cand. of Science of Law (Equiv. Ph.D.), Associate Professor of the Civil Law Department № 1, Yaroslav Mudryi National Law University, Kharkiv, Ukraine.n.ye.yarkina@nlu.edu.ua https://orcid. org/0000-0001-9026-9385

Co-author, responsible for data collection.

Competing interests: Any competing interests were announced.

Disclaimer: The author declares that her opinion and views expressed in this manuscript are free of any impact of any organizations.

3 Cand. of Science of Law (Equiv. Ph.D.), Associate Professor at the Department of Law, Lutsk National Technical University, Lutsk, Ukraine. Filiuk.alexandra@ltnu.ua, https://orcid.org/0000-0003-1717-3146 Co-author, responsible for data collection.

Competing interests: Any competing interests were announced.

Disclaimer: The author declares that her opinion and views expressed in this manuscript are free of any impact of any organizations. 
Submitted on 2 Sept 2021 / Revised on 16 0ct 2021 / Revised 2nd on 11 Dec 2021

Approved 14 Jan 2022 / Published 01 Feb 2022

Summary: - 1. Introduction. - 2. Classification of Grounds for Refusal to Recognise and Enforce the Award of International Commercial Arbitration. - 3 The Definition of 'Public Order' in the Doctrine of International Commercial Arbitration. - 4. Types of Public Order and the Practice of Application. - 5. Conclusions.

Keywords: public order; international commercial arbitration; recognition and enforcement of foreign decision.

\section{ABSTRACT}

Background: The question of recognition and enforcement of international commercial arbitration (ICA) decisions, as a prototype of a foreign court decision, finds radically opposite answers in different legal systems and in the doctrine of the ICA. Thus, in the Regulation of the Council (EU) 44/2001 of 22 December 2000 on the jurisdiction, recognition, and enforcement of judgments in civil and commercial matters, formerly the Brussels Convention of 1968 and the Lugano Convention of 1988, the notion of 'arbitration' was excluded from the sphere of execution and recognition of foreign court decisions.

Methods: Nevertheless, the procedure for recognising and enforcing an ICA award has a unified approach in many countries around the world. Thus, national courts, when deciding on the recognition and enforcement of an ICA award, are increasingly faced with such problematic issues as the grounds for refusing to recognise and enforce such an award. This article reveals that these grounds for refusing to recognise and enforce the award of the ICA are a violation of public order of the country where the arbitral award is subject to recognition and enforcement. Particular attention is paid to the distinction between 'substantive' and 'procedural' public order and the practical approaches of national courts in some countries to this issue.

Results and Conclusions: The authors state that the way to overcome this inconsistency is still a unified approach to understanding 'public order' in all member states of the New York Convention of 1958 and clearer international regulation of this issue.

\section{INTRODUCTION}

In the Code of Civil Procedure of Ukraine, ${ }^{4}$ Chapter 3 of Section IX bears the title 'Recognition and granting of permission to execute awards of international commercial arbitration. This legislative decision is explained by the fact that in this chapter, the legislator focuses on the recognition and enforcement of the awards of international commercial arbitration. Moreover, not only are the awards of a foreign ICA subject to recognition with the issuance of a permit for enforcement but also the voluntary execution of such decisions must be confirmed by the court consideration of the application for recognition and granting permission for voluntary execution of decisions on recovery of monetary funds.

The recognition and enforcement of ICA awards are more important issues in the arbitration mechanism for the settlement of disputes, which is governed by multilateral conventions,

$4 \quad$ Law of Ukraine 'Civil Procedure Code of Ukraine' of 18 March 2004 No 1618-IV (updated on 4 November 2018) <http://zakon.rada.gov.ua/laws/show/1618-15> accessed 16 October 2021. 
bilateral agreements, and national law. ${ }^{5}$ The most widely-used and successful instrument, as already noted, is the 1958 Convention on the Recognition and Enforcement of Foreign Arbitral Awards. ${ }^{6}$

Despite the universality of the New York Convention on the Recognition and Enforcement of Foreign Arbitral Awards of 1958 (hereafter - the New York Convention), it remains for the state court to recognise and enforce them and for state courts to consider applications for recognition and permission to enforce arbitral awards, and to refuse such recognition. In connection with the use, the problem of the relationship between the Convention and the domestic law of the countries in which the arbitral award is to be enforced arises.

The international legal regulation of the recognition and enforcement of arbitral awards was initially aimed at creating a regime of the imperative obligation of states to comply with arbitral awards rendered in their territory (internal arbitral awards). This provision was enshrined in Art. 3 of the Geneva Protocol on Arbitration Reservations of 1923. ${ }^{7}$ Later, in the Geneva Convention on the Enforcement of Foreign Arbitral Awards of 1927, member states undertook the enforcement in their territory of arbitral awards rendered in the territory of other member states to the Convention on the basis of arbitration agreements that fell under the Geneva Protocol of $1923 .^{8}$

Mechanisms for the recognition and enforcement of foreign and domestic arbitral awards in the international legal unification of ICA were formed gradually. However, neither the New York Convention nor other international conventions on international commercial arbitration contain the concept of an 'internal' arbitral award and general rules on the criteria for qualifying arbitral awards as 'foreign' or 'domestic'.

The scope of the New York Convention is defined extremely broadly. In accordance with para. 1 of Art. I of the Convention, a state shall recognise and enforce any arbitral award rendered outside the territory of the state in which such recognition and enforcement is required. In preparing the text of the New York Convention, proposals to narrow the scope of the Convention were rejected on the grounds that disputes referred to arbitration must include foreign elements. Thus, the member states to the Convention have, in essence, agreed to limit the powers of national courts to hear a large proportion of commercial disputes between individuals and legal entities that have close links with their territory. ${ }^{9}$

$5 \quad$ On bilateral agreements between Ukraine and the EU member states, see Iryna Izarova, 'Enhancing judicial cooperation in civil matters between the EU and Ukraine: first steps ahead', in A Trunk, N Hatzimihail (eds), EU Civil Procedure Law and Third Countries: Which Way Forward? (Nomos 2021) 191-212.

61958 Convention on the Recognition and Enforcement of Foreign Arbitral Awards <https://www. newyorkconvention.org/english > accessed 16 October 2021.

7 Protocol on Arbitration Reservations, Geneva, 24 September $1923<$ https://www.uncitral.org/pdf/ russian/publications/sales_publications/Register_texts_vol_II.pdf > accessed 16 October 2021.

8 Convention on the Enforcement of Foreign Arbitral Awards, Geneva, 26 September $1927<$ https:// www.uncitral.org/pdf/russian/publications/sales_publications/Register_texts_vol_II.pdf $>$ accessed 16 October 2021.

9 United Nations Conference on International Commercial Arbitration. Comments by Governments on Draft Convention on the Recognition and Enforcement of Foreign Arbitral Awards. E/ Conf. 26/3. 10 March 1958. P. 3 <http://www.newyorkconvention.org/travaux+preparatoires/ history+1923+-+1958> accessed 16 October 2021 . 


\section{CLASSIFICATION OF GROUNDS FOR REFUSAL TO RECOGNISE AND ENFORCE} THE AWARD OF ICA

A key issue in the procedure for the recognition and enforcement of foreign arbitral awards is the refusal of a national court to recognise and enforce foreign arbitral awards. Although the New York Convention provides the same grounds for refusing to recognise and enforce foreign arbitral awards in all contracting states, their application may lead to different results due to the peculiarities of the regulation of this issue by domestic law.

The New York Convention enshrines two exhaustive sets of grounds for denial of recognition and enforcement of arbitral awards. The first group of grounds includes the cases provided for in Art. V (1), when:

a) the parties to the agreement are incapable in some way or this agreement is invalid under the law to which the parties have subjected this agreement, and in the absence of such subordination, for the law of the country where the decision was made;

b) the party against whom the award has been made has not been duly notified of the appointment of the arbitrator or of the arbitral proceedings or has otherwise failed to submit their explanations;

c) the said decision is rendered on a dispute not provided for, or which does not fall under the terms of the arbitration agreement or arbitration clause in the contract, or contains rulings on issues beyond the arbitration agreement or arbitration clause in the contract;

d) the composition of the arbitral tribunal or the arbitral proceedings did not comply with the agreement of the parties or, failing that, did not comply with the law of the state where the arbitration took place;

e) the decision has not yet become final for the parties or has been revoked or suspended by the competent authority of the country where it was given or the country whose law is applicable.

The second group of grounds for a refusal to recognise and enforce foreign arbitral awards includes the cases provided for in Art. V (2) of the New York Convention:

a) the subject matter of the dispute may not be subject to arbitration under the laws of that country;

b) the recognition and enforcement of this decision are contrary to the public order of that country.

\section{THE DEFINITION OF 'PUBLIC ORDER' IN THE DOCTRINE OF INTERNATIONAL COMMERCIAL ARBITRATION}

Particular attention should be paid to such grounds for a refusal to recognise the enforcement of an ICA award as non-compliance with the public order of the country where the ICA award is subject to recognition and enforcement.

The issue of public order is one of the difficult problems of international commercial arbitration. Public order is a protective mechanism designed to protect the foundations of law and order that have developed at a certain point in time and are effective and necessary 
for the functioning of a given society. The legislation of almost all states and relevant international agreements enshrines a well-known rule: a foreign arbitral award is not enforceable if the court finds that such enforcement may cause a result that is incompatible with the law and order of the state (public order). However, in no legal system is there a clear legislative definition of the concept of 'public order'. There is also no unified approach to determining the content of public order in law enforcement practice and legal doctrine.

One of the most famous Ukrainian scholars, Vasyl Kysil, identifies elements that are mostly included in the content and can be a characteristic of such a concept as the 'foundations of law and order' of Ukraine:

a) the fundamental principles of the national law of Ukraine, which cover such imperative norms of public, private, and procedural law as constitute the skeleton of the rule of law in Ukraine;

b) universally recognised principles of morality and justice that are important for the Ukrainian legal order and prevailing in Ukrainian society;

c) the legitimate interests of Ukrainian individuals and legal entities, the Ukrainian state, and Ukrainian society, the protection of which is the main task of the Ukrainian legal system;

d) generally recognised principles and norms of international law that are part of the Ukrainian legal system and especially international human rights standards.

The author also notes that due to the inconsistency of doctrinal approaches, the legislators of most countries resort only to general formulations, so the ordre public reservations are very similar to each other in different laws. As a rule, explanations on the rules of application of the public order clause are given by the courts on the basis of the interpretation of the norms of law, the qualification of the factual composition of the case, and doctrinal statements. ${ }^{10}$

The concept of 'public order' is enshrined in some regulations of Ukraine. Thus, in accordance with para. 'b' item 2 part 2 of Art. 459 of the CPC of Ukraine, the decision of the ICA may be revoked if the court determines that the arbitral award is contrary to the public order of Ukraine. Para. 12 of the Resolution of the Plenum of the Supreme Court of Ukraine of 24 December 1999 no. 12 'On the Practice of Consideration by Courts of Requests for Recognition and Enforcement of Decisions of Foreign Courts and Arbitrations and Revocation of Decisions Ruled by ICA in Ukraine' stated that public order should be understood as the legal order of the state, the defining principles and regulations that form the basis of the system in it (concerning its independence, integrity, independence and inviolability, basic constitutional rights, freedoms, guarantees, etc.). ${ }^{11}$

Art. 12 of the Law of Ukraine 'On Private International Law'12 also contains reservations on public order, according to which the rule of foreign law is not applied in cases where its application leads to consequences that are clearly incompatible with the principles of law and order (public order) of Ukraine. In such cases, the law that is most closely related to the legal relationship is used, and if such a right cannot be determined or applied, the law of Ukraine is applied.

$\overline{10}$ AS Dowgert, VI Kisil (eds), International private law (К.: Алерта 2012) 228-229.

11 Resolution of the Plenum of the Supreme Court of Ukraine of 24 December 1999 no 12 'On the practice of consideration by courts of petitions for recognition and enforcement of decisions of foreign courts and arbitrations and revocation of decisions rendered by international commercial arbitration in Ukraine' <https://zakon.rada.gov.ua/laws/show/v0012700-99\#Text> accessed 16 October 2021.

12 Law of Ukraine 'On Private International Law' < https://zakon.rada.gov.ua/go/2709-15> accessed 16 October 2021. 


\section{TYPES OF PUBLIC ORDER AND PRACTICE OF APPLICATION}

The main feature of the protection of public order in many jurisdictions is the distinction between 'substantive' and 'procedural' public order. Therefore, in applying Art. V (2) (b) of the New York Convention, national courts consider not only the outcome of the arbitral award on the merits but also the procedure leading to such award, and in the case of substantial procedural irregularities in the arbitration proceedings, recognition, and enforcement in accordance with Art. V (2) (b).

National courts, when considering an application for recognition and enforcement of an arbitral award, may establish a violation of public order in cases where the right of the party to be heard has been violated. For example, the Quebec High Court, in Louis Dreyfus S.A.S. v. Holding Tusculum B.V., refused to recognise and enforce the arbitral award because the arbitral tribunal applied a remedy that went beyond the arbitration proceedings on the basis of the arguments of only one party. Therefore, the court ruled that such an arbitral award violates the principle of audiatur et altera pars (the other party should also be heard).$^{13}$

Another example of a breach of procedural public order is when arbitrators act in violation of the principles of independence and impartiality. For example, in Soc. Excelsior Film TV v. Soc. UGC-PH, the French Court of Cassation, which was involved in two parallel arbitrations between the same parties, one of the arbitrators who participated in the two arbitration proceedings provided false information about the essential terms of the case in one of the arbitration proceedings, which influenced the decision of this arbitral tribunal regarding its jurisdiction. In the present case, the French Court of Cassation found that in so doing the arbitrator had violated the principle of equality of parties of arbitration proceedings, which was contrary to the most basic requirements of due process. ${ }^{14}$

The District Court of Affoltern-on-Albis of Switzerland, in a decision of 24 March 1994, established that when the lawyer of one of the parties in the negotiations included in the contract a provision appointing himself as sole arbitrator in case of dispute between the parties, he had violated public order. The court found that the conduct of the arbitrator, Dr. E., was so extreme that it was difficult to imagine that any free and democratic legal system could equate an arbitral award rendered by such an arbitrator with an act of justice of a sovereign state and ensure its enforcement. It was absolutely unacceptable for a person who draws up a contract as an arbitrator to give it a binding interpretation, especially if he had been a lawyer for many years. ${ }^{15}$

An example of a breach of procedural public order may be a situation where two parties to a tripartite contact had to appoint one arbitrator. The Court of Cassation of France in the case of Siemens A.G. v. BKMI Industrienlagen $G m b H$ acknowledged that the principle of equality of parties in the appointment of arbitrators is part of the French understanding of international public order, which can be ignored only after a dispute has arisen. The court concluded that the decision rendered by the court of three arbitrators, one of whom had been appointed with objections jointly by the two defendants, should be cancelled. ${ }^{16}$

The Federal Supreme Court of Switzerland in the case of Egemetal Demir Celik Sanayive Ticaret A.S. v. Fuchs Systemtechnik GmbH stated that the main procedural guarantees, including the

13 Louis Dreyfus SAS v Holding Tusculum BV, Superior Court of Quebec, Canada, 12 December 2008 <http://newyorkconvention1958.org/index.php?lvl=notice_display\&id=959> accessed 16 October 2021.

14 Société Excelsior Film TV v Société UGC-PH, Court of Cassation, France, 24 March $1998<$ http:// newyorkconvention1958.org/index.php?lvl=notice_display\&id=152> accessed 16 October 2021.

15 Leon Trakman 'Domestic Courts Declining to Recognize and Enforce Foreign Arbitral Awards: A Comparative Reflection' (2018) 6 (2) The Chinese Journal of Comparative Law 174-227.

16 Siemens AG v BKMI Industrienlagen GmbH, Court of Cassation, France, 7 January $1992<$ https:// heinonline.org/HOL/P?h=hein.journals/intfinr12\&i=129> accessed 16 October 2021. 
principle of procedural public order, guarantee to ensure an independent decision-making process regarding those claims and objections of the parties that have been submitted to the arbitral tribunal in accordance with the relevant requirements of the procedural rules. ${ }^{17} \mathrm{In}$ another judgment of the Swiss Federal Supreme Court in case X (S.p.A.) v. Y (S.r.l.), the court stated that procedural public order is violated when fundamental and generally accepted principles are not followed, which leads to certain contradictions regarding the fair trial, so that the decision is inconsistent with the values recognised by the rule of law. ${ }^{18}$

Regarding the application of substantive public order, the following cases can be cited: violation of the principle of pacta sunt servenda; the principle of good faith and the prohibition of abuse of rights; property rights, such as expropriation without proper compensation; antitrust and competition law, including in the member states of the European Union (EU), the basic provisions of the EU on the common market; fiscal legislation, such as tax legislation, the law on currency control; laws on social protection, such as the law on consumer protection; foreign policy laws or other direct international obligations, such as export/import restrictions, embargoes, sanctions in UN Security Council resolutions. ${ }^{19}$

The national laws of the member states of the New York Convention, disclosing the content of public order, also distinguish between internal public order (ordre public interne) and international public order (ordre public international). According to this distinction, public order at the national level reflects the most fundamental concepts of morality and justice, recognised in the legal system of the state, and legal relations of an international nature fall under the standard of public order.

The distinction between the concept of international public order (ordre public international) and domestic public order (ordre public interne) is traced in the doctrine of international commercial arbitration. In countries such as Austria, Brazil, China, the Czech Republic, Hungary, Italy, Russia, Slovenia, Taiwan, the United Kingdom, and the United States, courts do not apply this distinction. National courts in countries such as Australia, Canada (at least in Quebec), Croatia, France, Germany, Italy, Portugal, Slovenia, Turkey, Uruguay, and Venezuela identify such differences. In Portugal, arbitration law explicitly provides that the recognition and enforcement of foreign judgments is subject to international rather than domestic public order. Pursuant to Art. 56 (1) (b) (ii)) of the Portuguese Law on Voluntary Arbitration, the court refuses to recognise and enforce a foreign arbitral award if it leads to a result that is manifestly incompatible with international public order in Portugal. ${ }^{20}$

It is also pertinent to emphasise that in some countries, in particular France and Switzerland, courts deliberately use this difference. For example, the French Supreme Court in Société SNF v. Société Cytec, the French Court of Cassation notes that a breach of international public order occurs only when, in certain circumstances, such a breach can be described as 'effective and specific', 'gross' or 'deliberate.. ${ }^{21}$

17 Egemetal Demir Celik Sanayi ve Ticaret AS v Fuchs Systemtechnik GmbH (2000) (Switz.) $<$ http://relevancy.bger.ch/php/clir/http/index.php?highlight_docid=atf\%3A\%2F\%2F126-III249\%3Ait\&lang=it\&type=show_document $>$ accessed 16 October 2021.

$18 X$ SpA v Y Srl, Federal Tribunal, Switzerland, 8 March 2006, Arrêts du Tribunal Fédéral (2006) 132 III $389<$ http://www.swissarbitrationdecisions.com/sites/default/files/8\%20mars\%202006\%204P\%20 278\%202005.pdf > accessed 16 October 2021.

19 Steiner Szabolcs, 'Public order as ground for refusal of recognition of foreign arbitral awards with special focus on Austria and Hungary' <http://www.etd.ceu.hu/2012/steiner_szabolcs.pdf > accessed 16 October 2021.

20 Portuguese Voluntary Arbitration Law $2011<$ https://a.storyblok.com/f/46533/x/68d5f16880/thenew-law-on-voluntary-arbitration.pdf $>$ accessed 16 October 2021.

21 Société SNF $v$ Société Cytec, Court of Cassation, France <https://www.legifrance.gouv.fr/ affichJuriJudi.do?idTexte=JURITEXT000018947552> accessed 16 October 2021. 
Due to the lack of clear legal regulation of the concept of 'public order' in Ukraine, a certain approach is reflected in the practice of national courts. Thus, in accordance with the position of the Supreme Court, public order should be understood as the rule of law of the state and certain principles and guidelines that form the basis of its existing system (concerning its independence, integrity, sovereignty, and inviolability and basic constitutional rights, freedoms, guarantees, etc.). ${ }^{22}$ The international public order of any country includes the fundamental principles and principles of justice, the morals that the state wishes to protect even when it is not directly related to the state itself; rules that ensure the fundamental political, social, and economic interests of the state (rules of public order) - the obligation of a state to comply with its obligations to other states and international organisations. These are the unchanging principles that express the stability of the international system: including the sovereignty of the state, non-interference in the internal affairs of states, non-violation of territorial integrity, and so on.

According to the position of the Supreme Court, it is stated that the legal concept of public order exists to protect the state from foreign arbitration awards that violate the fundamental principles of justice and judicature in the state. These provisions are intended to establish a legal barrier to decisions taken contrary to the fundamental procedural and substantive principles of public and state order. They are also designed to prevent the possibility of recognising and authorising the execution of decisions related to the corruption or unacceptable ignorance of arbitrators. ${ }^{23}$

An unjustified refusal to grant permission to enforce a decision of the ICA Court is a kind of blocking of the decision and is an artificial regulatory barrier, which is absolutely unacceptable from the point of view of international law. This block will not only not meet the objectives of international arbitration but will also violate the legal rights that this arbitral award may actually grant to the claimant in other countries.

Refusal to recognise and grant permission for enforcement on the territory of Ukraine of the arbitral award will violate part one of Art. 1 of Protocol No. 1 to the Convention for the Protection of Human Rights and Fundamental Freedoms, will interfere with the claimant's ownership of the awarded funds (decision in the case of Stran Greek Refineries and Stratis Andreadis v. Greece of 9 December 1994, Series A, no. 301-B).

The reservation on public order in general is formulated in international conventions. In particular, Art. 6 of the UN Convention on the Law Applicable to the International Sale of Goods of 15 June 1995 states that in each of the contracting states, the application of the law defined by this Convention may be excluded for reasons of public order. The same rule is laid down in Art. 18 of the UN Convention on the Law Applicable to Contracts for the International Sale of Goods of 22 December 1986. Thus, the main task of the reservation on public order in international law is to resolve conflicts between different countries.

The object of the reservation on public order is international private law relations, and the subject is non-application of foreign law, which is chosen to regulate civil relations with a foreign element, if its application violates the public order of the state. In this case, the reservation on public order will regulate an independent sphere of public relations, which does not depend on the sphere of interstate relations.

22 Resolution of the Civil Court of Cassation of the Supreme Court of 29 November 2018 in case no 760/5924/17 on the application of the Limited Liability Company 'CITIPORT' on the recognition and granting of permission to enforce the decision of the International Commercial Arbitration Court at Trade-Industrial Chamber of Ukraine of 21 January 2016 in the case of AU no 611r/2015.

23 Resolution of the Civil Court of Cassation of the Supreme Court of 5 September 2018 in case no $761 / 46285 / 16$-c on the claim of the Joint-Stock Company 'Avia-FED-Service' to grant permission to enforce the decision of the International Commercial Arbitration Court at the Chamber of Industry of the Russian Federation of 3 October 2016 in case no 300/2015. 
Art. 12 of the Law of Ukraine 'On Private International Law' stipulates that a rule of law of a foreign state is not applied in cases where its application leads to consequences that are clearly incompatible with the principles of law and order (public order) of Ukraine. ${ }^{24}$ In such cases, the law that has the closest connection with legal relations is applied, and if such right cannot be defined or applied, the law of Ukraine is applied. If the court considers the disputed legal relationship on the basis of an agreement between the parties, the public order of this state is not directly affected. In view of the above, a reference to a breach of public order may take place only in cases where the execution of a foreign arbitral award is incompatible with the foundations of the rule of law of the state. ${ }^{25}$

A clearer approach to the understanding of 'public order' is reflected in the dissenting opinion of the judge, which states that the definition of 'public order' should take into account the recommendations of the Association of International Law on Public Order, adopted in New Delhi in 2002, which state that the finality of arbitral awards in ICA should be respected except in exceptional circumstances. ${ }^{26}$

According to para. 1 (d) of these recommendations, the international public order of any state includes:

(I) the fundamental principles of justice or morality which the state wishes to protect, even if it has not been directly involved in the dispute;

(II) rules designed to serve the fundamental political, social, or economic interests of the state, known as lois de polis or 'rules of public order'; and

(III) the duty of a state to comply with its obligations to other states or international organisations.

A breach of public order will occur if the recognition and enforcement of a foreign arbitral award in a particular case are so contrary to national law that it is inadmissible under national law.

Under this approach, foreign arbitral awards, the enforcement of which may conflict with the mandatory rules of the national law of the country where enforcement is sought, or with the rules of international treaties of such a country, are recognised as contrary to public order and are not enforceable. ${ }^{27}$

\section{CONCLUSIONS}

Thus, it is clear that the rules of the New York Convention, although they contain exclusive grounds for refusing to recognise and enforce foreign arbitral awards, the national laws and courts of the member states regulate this issue, taking into account the specifics of their own legal systems. This is especially true regarding approaches to the definition and practice of public order as grounds for refusing to recognise and enforce an ICA award. We believe that

24 Iryna Izarova, 'Strengthening Judicial cooperation in civil matters between the EU and neighboring countries: the example of Ukraine and the Baltic states' (2019) 12 (2) Baltic Journal of Law \& Politics 115-133. https://doi.org/10.2478/bjlp-2019-0014

25 Resolution of the Civil Court of Cassation of 5 September 2018 in case no 761/46285/16-t $<\mathrm{http} / / /$ reyestr.court.gov.ua/Review/76502952> accessed 16 October 2021.

26 Opinion of a judge of the First Judicial Chamber of the Civil Court of Cassation in the Supreme Court Karpenko SO from 27 March 2019 in case no 756/618/14-c.

27 Separate opinion of the Judge of the First Judicial Chamber of the Civil Court of Cassation as a part of the Supreme Court Karpenko SO dated 27 March 2019 in case no 756/618/14-t <http://reyestr. court.gov.ua/Review/82885459> accessed 16 October 2021. 
the only way to overcome this inconsistency is still a unified approach to understanding 'public order' in all member states of the New York Convention and a clearer international regulation of this issue.

\section{REFERENCES}

1. Law of Ukraine 'Civil Procedure Code of Ukraine' of 18 March 2004 No 1618-IV (updated on 4 November 2018) <http://zakon.rada.gov.ua/laws/show/1618-15> accessed 16 October 2021.

2. Izarova Iryna, 'Enhancing judicial cooperation in civil matters between the EU and Ukraine: first steps ahead', in A Trunk, N Hatzimihail (eds), EU Civil Procedure Law and Third Countries: Which Way Forward? (Nomos 2021) 191-212.

3. 1958 Convention on the Recognition and Enforcement of Foreign Arbitral Awards <https:// www.newyorkconvention.org/english > accessed 16 October 2021.

4. Protocol on Arbitration Reservations, Geneva, 24 September $1923<$ https://www.uncitral. org/pdf/russian/publications/sales_publications/Register_texts_vol_Il.pdf> accessed 16 October 2021.

5. Convention on the Enforcement of Foreign Arbitral Awards, Geneva, 26 September 1927 $<$ https://www.uncitral.org/pdf/russian/publications/sales_publications/Register_texts_ vol_Il.pdf $>$ accessed 16 October 2021.

6. United Nations Conference on International Commercial Arbitration. Comments by Governments on Draft Convention on the Recognition and Enforcement of Foreign Arbitral Awards. E/Conf. 26/3. 10 March 1958. P. 3 <http://www.newyorkconvention.org/ travaux+preparatoires/history+1923+-+1958> accessed 16 October 2021.

7. Dowgert AS, Kisil VI (eds), International private law (К.: Алерта 2012) 228-229.

8. Resolution of the Plenum of the Supreme Court of Ukraine of 24 December 1999 no 12 'On the practice of consideration by courts of petitions for recognition and enforcement of decisions of foreign courts and arbitrations and revocation of decisions rendered by international commercial arbitration in Ukraine' <https://zakon.rada.gov.ua/laws/show/ v0012700-99\#Text> accessed 16 October 2021.

9. Law of Ukraine 'On Private International Law' <https://zakon.rada.gov.ua/go/2709-15> accessed 16 October 2021.

10. Louis Dreyfus SAS v Holding Tusculum BV, Superior Court of Quebec, Canada, 12 December 2008 $<$ http://newyorkconvention1958.org/index.php?lvl=notice_display\&id=959> accessed 16 October 2021.

11. Société Excelsior Film TV v Société UGC-PH, Court of Cassation, France, 24 March 1998 $<$ http://newyorkconvention1958.org/index.php?lvl=notice_display\&id=152> accessed 16 October 2021.

12. Trakman Leon, 'Domestic Courts Declining to Recognize and Enforce Foreign Arbitral Awards: A Comparative Reflection' (2018) 6 (2) The Chinese Journal of Comparative Law 174-227.

13. Siemens $A G$ v BKMI Industrienlagen $\mathrm{GmbH}$, Court of Cassation, France, 7 January 1992 $<$ https://heinonline.org/HOL/P?h=hein.journals/intfinr12\&i=129> accessed 16 October 2021.

14. Egemetal Demir Celik Sanayi ve Ticaret AS v Fuchs Systemtechnik GmbH (2000) (Switz.) $<$ http://relevancy.bger.ch/php/clir/http/index.php?highlight_docid=atf\%3A\%2F\%2F126III-249\%3Ait\&lang=it\&type=show_document> accessed 16 October 2021. 
15. XSpA v Y Srl, Federal Tribunal, Switzerland, 8 March 2006, Arrêts du Tribunal Fédéral (2006) 132 III 389 <http://www.swissarbitrationdecisions.com/sites/default/files/8\%20mars\%20 2006\%204P\%20278\%202005.pdf> accessed 16 October 2021.

16. Szabolcs Steiner, 'Public order as ground for refusal of recognition of foreign arbitral awards with special focus on Austria and Hungary'<http://www.etd.ceu.hu/2012/steiner_szabolcs. pdf> accessed 16 October 2021.

17. Portuguese Voluntary Arbitration Law 2011 <https://a.storyblok.com/f/46533/ x/68d5f16880/the-new-law-on-voluntary-arbitration.pdf > accessed 16 October 2021.

18. Société SNF v Société Cytec, Court of Cassation, France <https://www.legifrance.gouv.fr/ affichJuriJudi.do?idTexte=JURITEXT000018947552> accessed 16 October 2021.

19. Resolution of the Civil Court of Cassation of the Supreme Court of 29 November 2018 in case no 760/5924/17 on the application of the Limited Liability Company 'CITIPORT' on the recognition and granting of permission to enforce the decision of the International Commercial Arbitration Court at Trade-Industrial Chamber of Ukraine of 21 January 2016 in the case of AU no 611r/2015.

20. Resolution of the Civil Court of Cassation of the Supreme Court of 5 September 2018 in case no 761/46285/16-c on the claim of the Joint-Stock Company 'Avia-FED-Service' to grant permission to enforce the decision of the International Commercial Arbitration Court at the Chamber of Industry of the Russian Federation of 3 October 2016 in case no 300/2015.

21. Izarova Iryna, 'Strengthening Judicial cooperation in civil matters between the EU and neighboring countries: the example of Ukraine and the Baltic states' (2019) 12 (2) Baltic Journal of Law \& Politics 115-133. https://doi.org/10.2478/bjlp-2019-0014

22. Resolution of the Civil Court of Cassation of 5 September 2018 in case no 761/46285/16-t <http://reyestr.court.gov.ua/Review/76502952> accessed 16 October 2021.

23. Opinion of a judge of the First Judicial Chamber of the Civil Court of Cassation in the Supreme Court Karpenko SO from 27 March 2019 in case no 756/618/14-c.

24. Separate opinion of the Judge of the First Judicial Chamber of the Civil Court of Cassation as a part of the Supreme Court Karpenko SO dated 27 March 2019 in case no 756/618/14-t <http://reyestr.court.gov.ua/Review/82885459> accessed 16 October 2021. 